\title{
Effects of ascorbic and $\alpha$-lipoic acid on secretion of HSP- 70 and apoptosis in liver and kidneys of broilers exposed to heat stress
}

\author{
Kübra Asena TERIMM KAPAKİN ${ }^{1}$, Recep GÜMÜŞ ${ }^{2}$, Halit İMİK², Samet KAPAKİN ${ }^{3}$, \\ Yavuz Selim SAĞLAM ${ }^{1}$
}

1 Department of Pathology, Faculty of Veterinary Medicine, Atatürk University, Erzurum; 2Department of Animal Nutrition and Nutritional Disorders, Faculty of Veterinary Medicine, Atatürk University, Erzurum; 3Department of Anatomy, Faculty of Medicine, Atatürk University, Erzurum, Turkey.

\begin{abstract}
Summary: The objective of this experiment was to evaluate the ameliorative effect of L-ascorbic acid (AA) and $\alpha$-lipoic acid (ALA) on tissue damage caused by heat stress (HS) in the liver and kidneys of broilers, and to correlate this effect with the secretion of the heat shock protein-70 (HSP-70) protein and apoptosis. The study broilers of breed Ross 308 were used. Animals included in the control were divided into four groups. Group TN; control thermoneutral broilers $\left(24{ }^{\circ} \mathrm{C}\right)$ were not administered with antioxidants in the diet and not subjected to heat stress (TN). Group HS; broilers not administered with antioxidants in the diet but subjected to heat stress $\left(34{ }^{0} \mathrm{C}\right)(\mathrm{HS})$. Group HS+AA; broilers subjected to heat stress $\left(34{ }^{0} \mathrm{C}\right)$ and administered with ascorbic acide (AA). HS+ALA; broilers subjected to heat stress $\left(34{ }^{\circ} \mathrm{C}\right)$ and administered with $\alpha$ - lipoic acid (AAA). Then, all of the groups were sacrificed and organs (liver and kidney) were collected for histopathological and immunohistochemstry evaluations. Histopathological examination demonstrated that, in the liver and kidneys in Group HS, the blood vessels were very hyperemic. Hepatocytes as well as in tubulo epithelial cells of kidney displayed degenerative alterations. Lesions similar to those observed in Group HS were also observed in Groups HS+AA and HS+ALA. However, the liver and kidney HSP-70 secration were greater in Groups HS+AA, HS+ALA and TN than in Groups HS. The greatest number of apoptotic cells was determined in Group HS, whilst the lowest numbers were determined in Groups TN and HS+ALA. Dietary supplementation with ALA was more effective than AA at preventing tissue damage.
\end{abstract}

Key words: Ascorbic acid, $\alpha$-lipoic acid, apoptosis, broiler, heat shock proteins, heat stress.

\section{Sıcaklık stresine maruz bırakılan broilerlerin karaciğer ve böbreklerinde $\alpha$-lipoik ve askorbik asitin HSP- 70 sekresyonu ve apoptosis üzerine etkileri}

\footnotetext{
Özet: Bu çalışmada sıcaklık stresinin broilerlerin böbrek ve karaciğerlerinde meydana getireceği doku hasarı üzerine Laskorbik (AA) ve $\alpha$ - lipoik (ALA) asit'in koruyucu etkinin varlığı ve bu etkide HSP-70 salınımı ile apoptozis arasındaki ilişkinin saptanması amaçlanmıştır. Çalışmada toplam 278 Ross 308 rrkı broiler kullanıldı. Hayvanlar kontrol grubuda dahil 4 gruba ayrıldı. Grup TN; sıcaklık stresine maruz birakılmayan $\left(24^{\circ} \mathrm{C}\right)$ ve diyetlerine antioksidan eklenmeyen termonötral kontrol broiler (TN). Grup HS; sicaklık stresine maruz birakılan $\left(34{ }^{\circ} \mathrm{C}\right)$ ancak diyetlerine antioksidan eklenen broiler (HS). Grup HS+AA; sicaklik stresine maruz bırakılan $\left(34{ }^{\circ} \mathrm{C}\right)$ ancak diyetlerine askorbik asit (AA) eklenen broiler. Grup HS+AAA; sicaklık stresine maruz bırakılan (34 ${ }^{0} \mathrm{C}$ ) ancak diyetlerine $\alpha$ - lipoik asit (ALA) eklenen broiler. Sonra, grupların tamamı öldürüldü ve organlar (karaciğer ve böbrek) histopatolojik ve immunohistokimyasal değerlendirmeler için topland. Histopatolojik muayenelerde HS grubunun karaciğer ve böbreklerinde damarların oldukça hiperemik olduğu gözlendi. Hepatositlerde olduğu kadar böbrek epitel hücrelerinde de dejeneratif değişikler gözlendi. HS grubunda gözlenen lezyonların benzeri HS+AA, HS+ALA gruplarında da gözlendi. Ancak böbrek ve karaciğerde HSP-70 sekresyonu HS ve TN gruplarıyla kıyaslandığında HS+AA and HS+ALA gruplarında daha fazlaydı. Apoptotik hücre sayısı en fazla HS grubunda gözlenirken, en düşük hücre sayısı TN ve HS+ALA gruplarında gözlendi. Diyete eklenen ALA'nın doku hasarını önlemede AA'ya göre çok daha etkili olduğu gözlendi.

Anahtar sözcükler: Askorbik asit, $\alpha$-lipoik asit, apoptozis, broiler, 1S1 şok proteini, sıcaklık stresi.
}

\section{Introduction}

Heat stress (HS) is one of the most challenging environmental conditions affecting commercial poultry production and causes significant economic losses in the poultry industry $(4,14)$. Poultry have no sweat glands and a rapid metabolism, so they are particularly sensitive to high ambient temperatures. Heat stress reduces several physiological and metabolic factors in poultry such as weight gain, feed efficiency, serum total protein, albumin, triglycerides and uric acid $(26,28)$.

High stress also causes oxidative stress and thus weakens the in vivo antioxidant defence system $(13,14)$. 
The role of dietary supplements such as vitamins for alleviating the effects of heat stress in poultry has been reviewed extensively (13). Ascorbic acid (AA) (11) and $\alpha$-lipoic acid (ALA) (5) are primary antioxidants in biological systems and are capable of breaking the chain of lipid peroxidation in cell membranes.

Heat shock proteins (HSP) are a group of highly conserved proteins that are constitutively expressed in most cells under normal physiological conditions in every organism from bacteria to man (1). They make up approximately $5-10 \%$ of the total protein content of cells under conditions of normal, healthy growth (18) and are expressed or increased in response to various biological stressors, including high temperatures $(24,31)$ viral infections, inflammation $(16,30)$, malignant tumors (27), alcohol, toxic chemicals, and radiation (1). They also involve in both intracellular and extracellular immune functions (18) and apoptosis (12). Heat shock protein family consist of six groups; HSP-110, HSP-90, HSP-70, HSP-60, HSP-40 and small HSPs (Ubiquitin and HSP-27 (1). The most durable and best studied group in organisms is the members of HSP-70 family (1). The HSP-70 family performs a series of biological functions such as serving as a molecular chaperone, assisting immune responses (18), anti-apoptosis (12) and enhancing tolerance to stressors (1), among others. These processes are also involved in the production of reactive oxygen species (ROS), suggesting that oxidative stress is a key mechanism mediating HSP induction (15).

Apoptosis, or programmed cell death, is a physiological, genetically controlled, cellular response to external and internal stimuli whose purpose is to eliminate unwanted cells, including infected cells, while preventing damage to surrounding cells or tissue (3). The correlation of content of alpha-lipoic acid (ALA) $(6,10)$ and ascorbic acid (AA) $(14,24)$ with the secretion of HSP has been investigated in previous studies.

However, only a limited number of immunohistochemical studies are available regarding the production of the HSP-70 protein in poultry subjected to heat stress and the correlation between this protein and apoptosis.

In the present study, the mechanism of heat stressinduced hepatic and renal damage related to HSP-70 secretion and apoptosis was demonstrated in broilers by using histopathological and immunohistochemical methods and investigated the role of alpha-lipoic acid and ascorbic acid in this mechanism.

\section{Materials and Methods}

1. Animals, diet, experimental system: This study was approved by the Ethics Committee of the Faculty of Veterinary Medicine in Ataturk University (Decision No: 2007/5f). The trial was conducted at the Research and Practice Farm of Atatürk University, Faculty of Veterinary Medicine in 4 groups of animals (broilers of the commercial breed Ross 308). There were 24 cages in total, with six cages (as replicates) of 11 or 12 broilers per cage for each treatment group. Animals in each subgroup were kept within the cages $100 \times 55 \times 35 \mathrm{~cm}$ in size and fed from day 1 to day 42 . The trial groups were designed as follows: Group TN: control thermoneutral broilers $(n=70)$ were not administered with antioxidants in the diet and not subjected to heat stress (TN), Group HS: broilers not administered with antioxidants in the diet but subjected to heat stress (HS) ( $\mathrm{n}=67)$, Group HS+AA: broilers subjected to heat stress and administered with vitamin $\mathrm{C}$ (AA; vitamin C: $250 \mathrm{mg}$ of $\mathrm{L}$-ascorbic $\mathrm{acid} / \mathrm{kg}$ of diet), $(\mathrm{n}=71)$ HS+ALA: broilers subjected to heat stress and administered with $\alpha$-lipoic acid (ALA; Lipoic acid: $250 \mathrm{mg} \alpha$-lipoic acid $/ \mathrm{kg}$ of diet) $(\mathrm{n}=70)$ (Table 1). All groups were exposed to a comfortable temperature until day 14 of the trial. Beginning on day 15 , Groups HS, HS+AA and HS+ALA were subjected to a temperature of $34^{\circ} \mathrm{C}$ between $8^{00}$ and $16^{00}$ hours, and to a temperature of $24{ }^{\circ} \mathrm{C}$ for the rest of the $24 \mathrm{~h}$ day. Group TN was subjected to a temperature of $24^{\circ} \mathrm{C}$ throughout the trial. All groups were exposed to a daily regime of $17 \mathrm{hr}$ light and $7 \mathrm{hr}$ darkness. Dietary nutrient proportions were determined in compliance with the recommendations of the National Research Council (19). The composition of the ration used in the trial is given in Table 2.

Table 1. Experimental groups

Tablo 1. Deney grupları

\begin{tabular}{lcccc}
\hline Treatment & $\begin{array}{c}\text { Control } \\
\text { (TN) }\end{array}$ & $\begin{array}{c}\text { Stress } \\
\text { (HS) }\end{array}$ & $\begin{array}{c}\text { Ascorbic acid } \\
\text { (AA) }\end{array}$ & $\begin{array}{c}\text { Lipoic acid } \\
\text { (ALA) }\end{array}$ \\
\hline Heat stress & - & + & - & - \\
Ascorbic acid & - & + & + & - \\
$\alpha$-lipoic acid & - & + & - & + \\
\hline
\end{tabular}

At the end of the trial (Day 42), 10 broiler were selected randomly from each group $(n=40)$ and were killed by cervical dislocation for necropsy. Kidneys and liver were collected immediately for histopathological and immunohistochemical evaluations.

2. Histopathological and immunohistochemical examinations:

Histopathology: The tissues were removed and immediately half of them were fixed in $10 \%$ neutral buffered formalin. After dehydration in a graded ethanol series and clearing with xylene, the sample material was embedded in paraffin and $4-\mu \mathrm{m}$-thick sections were stained with Hematoxylin-Eosin for observation under the light microscope.

HSP-70 protein immunostaining: Four $\mu \mathrm{m}$ sections from all the tissue samples were cut and processed for 
Table 2. Crude nutrient proportions of ingredients in the basal ration Tablo 2. Bazal rasyonda besin içeriklerinin ham madde oranları

\begin{tabular}{lccc}
\hline Ingredients & $\begin{array}{c}\text { Starter } \\
\text { 1-15.day (\%) }\end{array}$ & $\begin{array}{c}\text { Grower } \\
\text { 16-28.day (\%) }\end{array}$ & $\begin{array}{c}\text { Finisher } \\
\text { 29-42.day (\%) }\end{array}$ \\
\hline Corn (8.5\% CP) & 56.99 & 58.74 & 64.16 \\
Corn gluten (60\%CP) & 20.00 & 20.00 & 20.00 \\
Boncalite & 7.00 & 7.00 & 7.00 \\
Soybean oil & 0.78 & 3.72 & 3.22 \\
Soybean meal(48\% CP) & 11.53 & 7.14 & 1.99 \\
Calcium carbonate & 1.36 & 1.23 & 1.18 \\
Dicalcium phosphate & 1.06 & 0.91 & 1.00 \\
L-lysine & 0.40 & 0.42 & 0.56 \\
Salt & 0.26 & 0.27 & 0.27 \\
Vitamin-Mineral premix $0.2 \%$ & 0.20 & 0.20 & 0.25 \\
Toxin binder & 0.10 & 0.10 & 0.10 \\
Anticoccidial & 0.10 & 0.10 & 0.10 \\
Sodium bicarbonate & 0.10 & 0.09 & 0.09 \\
Growth factor & 0.05 & 0.05 & 0.05 \\
Phyzyme XP TPT & 0.03 & 0.03 & 0.03 \\
DL-Methionine 98 \% & 0.04 & - & - \\
Nutritional levels & & & 3200 \\
\hline Metabolic Energy kcal/kg & & 3200 & 19 \\
Crude Protein \% & 3000 & 21 & \\
\hline
\end{tabular}

immunohistochemical examination by a standard avidinbiotin-peroxidase method as described by the producer. Mouse monoclonal antibodies that react with human HSP-70 (Clone: BRM-22, Sigma, St. Louis, MO, USA) were used at dilution of 1:5000 for $60 \mathrm{~min}$, respectively. The sections were then treated with Diaminobenzidine (DAB) as chromogen for $5 \mathrm{~min}$, washed with PBS and counterstained with Mayer's hematoxylin. Negative control tissue sections were incubated with mouse monoclonal serum.

Detection of apoptotic cells: Apoptotic cells were detected by terminal deoxynucleotidyl transferasemediated dUTP nick end labelling (TUNEL) stain using a commercial ready-to-use kit (In Situ Cell Death Detection Kit, POD, Roche, Mannheim, Germany). Briefly, paraffin sections $(4 \mu \mathrm{m})$ were mounted on silanized slides. After deparaffinization and rehydration, sections were digested with proteinase K $(20 \mu \mathrm{g} / \mathrm{ml}, 30$ min) and quenched with $3 \%$ hydrogen peroxide in methanole. Sections were incubated in a humidified chamber in $200 \mu \mathrm{l}$ of TUNEL (TdT and label solution) at $37^{\circ} \mathrm{C}$ for $60 \mathrm{~min}$ and with POD converter at $37^{\circ} \mathrm{C}$ for 30 min. The sections were then treated with Diaminobenzidine (DAB) as chromogen for $5 \mathrm{~min}$, washed with PBS and counterstained with Mayer's hematoxylin.

Tissue section evaluated by high pover light microscopic examination Olympus Bx52 with DP72 camera system. All immunohistochemical staining were estimated with an image processing system (Olympus, DP2-BSW). For each specimen, HSP -70 and TUNEL stain were examined in 10 randomly selected areas of approximately X40 objective. The scores were derived semi-quantitatively using light microscopy on the preparations from each animal and were reported as follows: none: - , mild: + , moderate: ++ , severe: +++ , and very strong: ++++ .

3. Statistical analysis: The data were analyzed statistically using the Kruskal-Wallis Test of nonparametric tests. A value $P<0.05$ was considered significant (29).

\section{Results}

Macroscopic findings: Liver and kidneys looked hyperemic and swollen in all animals of Group HS, in 6 of the animals of Group HS+AA, and in 5 of the animals of Group HS+ALA. No macroscopic finding was observed in the liver and kidneys of the animals included in Group TN.

Microscopic and immunohistochemical findings: Histopathological examination of the control animals (Group TN) showed normal hepatic and renal tissue histology. Histopathological examination demonstrated that, in the HS group, remarkable degenerative changes were prominent. Hepatocytes were swollen and eosinophilic in appearance, and the hepatic cords were diffuse and disorganized (Figure 1a). In addition to these changes, inflammatory cells had infiltrated within portal areas, and proliferation of Kupffer cells, and hyperplasia of bile ducts and focal congestion of the sinusoids with extensive hemorrhages were observed. Lesions similar to those observed in Group HS were also observed in the liver of the animals included in Groups HS+AA and 
HS+ALA. However, these degenerative and inflammatory changes generally were reduced in the HS+AA and HS+ALA groups (Figures $1 \mathrm{~b}-\mathrm{c}$ ). While severe lesions were observed in the liver in Group HS, the severity lesions were reduced in Groups HS+AA and HS+ALA $\left(\mathrm{X}_{3}^{2}=28.55, \mathrm{P}<0.000\right)$ (Figure 2a).
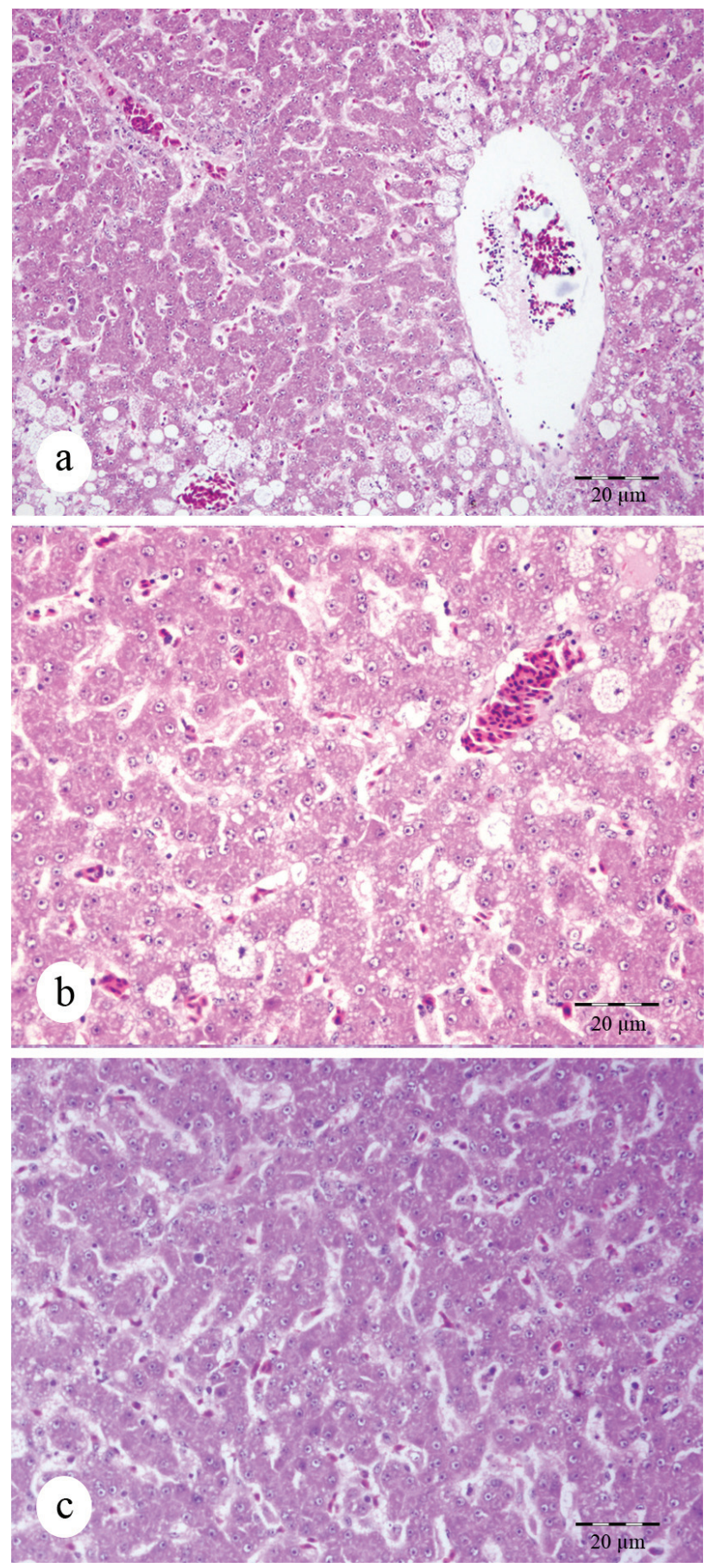

Figures 1 a-b-c: Hepatocytes displayed degenerative alterations, a. Intensive (Group heat stress), HE., Bar: $20 \mu \mathrm{m}$. b. Moderate (Ascorbic acid), HE., Bar: $20 \mu \mathrm{m}$. c. Weak ( $\alpha-$ lipoic acid) HE., Bar: $20 \mu \mathrm{m}$.

Şekil 1a-b-c: Hepatositlerde dejeneratif değişiklikler, a. Yoğun (sicaklık stresi uygulanan grup), Bar: $20 \mu \mathrm{m}$. b. Orta (Askorbik asit), Bar: $20 \mu \mathrm{m}$ c. Hafif ( $\alpha$-lipoik asit ) Bar: $20 \mu \mathrm{m}$.
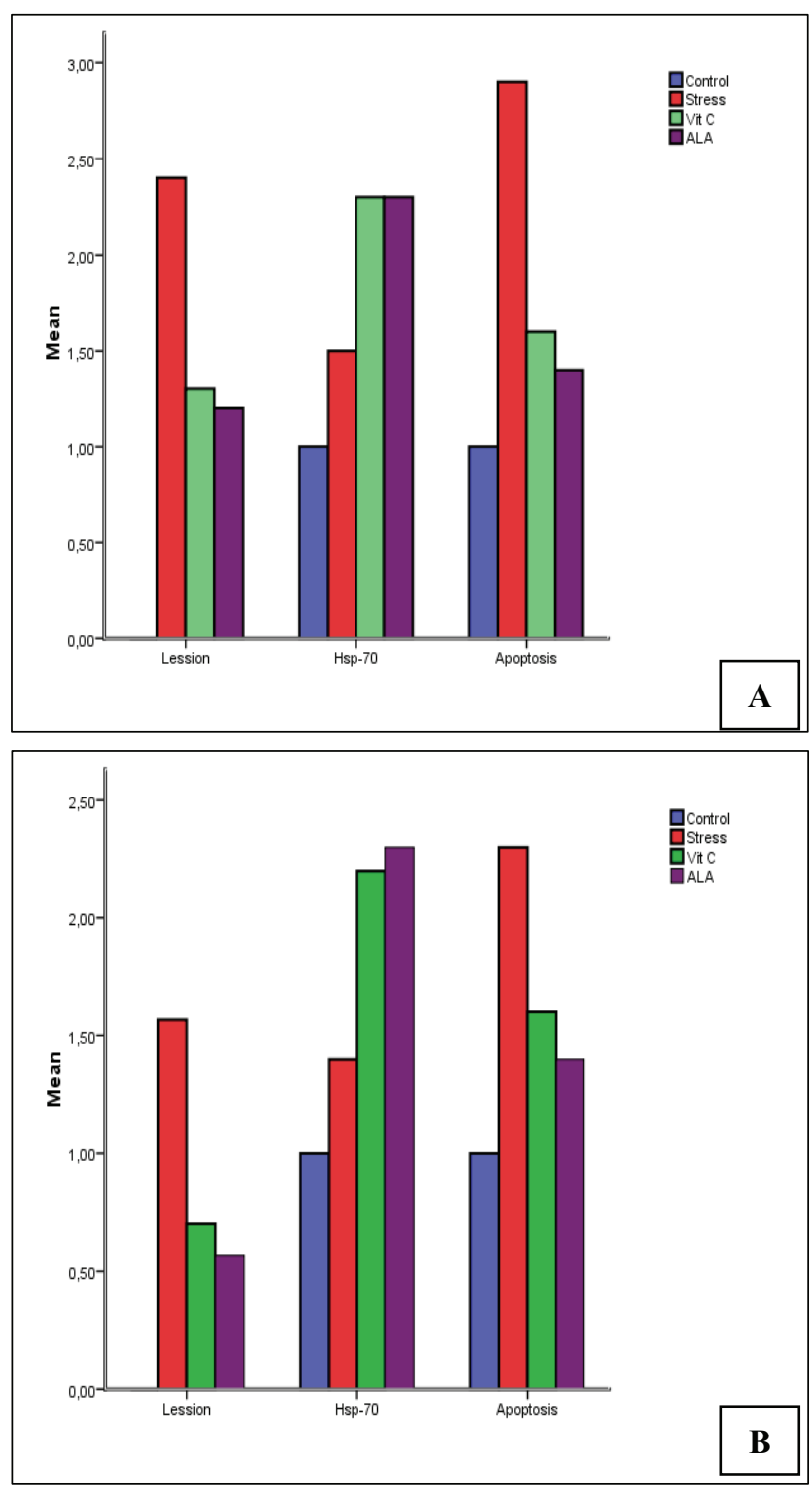

Figure 2. A: Effects of ascorbic and $\alpha$-lipoic acid, with different staining methods on liver (Panel A) tissues which is damaged by heat stress. $\left(\mathrm{X}_{3}{ }^{2}=28.55, \mathrm{P}<0.000\right)$, B: Effects of ascorbic and $\alpha$ - lipoic acid, with different staining methods, on kidney (Panel B) tissues which is damaged by heat stress $\left(\mathrm{X}_{3}^{2}=29.93, \mathrm{P}<0.000\right)$

Şekil 2. A: Farklı boyama metodları ile sıcaklık stresinin karaciğerde (Panel A) meydana getirdiği hasar üzerine askorbik ve $\alpha$ - lipoik asitin etkisi. B: Farklı boyama metodları ile sıcaklık stresinin böbreklerde (Panel B) meydana getirdiği hasar üzerine askorbik ve $\alpha$ - lipoik asitin etkisi.

Histopathological examination demonstrated that, in the group HS, the blood vessels of the kidneys were also very hyperemic and erythrocytes were present in the intertubular regions. Many tubules showed various degenerative changes (Figure 3a). Also inflammatory cells were observed partly in the intertubular regions. Lesions similar to those observed in Group HS were also observed in the kidneys of the animals included in Groups HS+AA and HS+ALA. However, these degenerative and inflammatory changes generally were reduced in the HS+AA and HS+ALA groups (Figure 3b- 
c). The marked level of renal lesions was observed in Group HS, whilst the severe of lesions were weak in Groups HS+AA and HS+ALA $\left(\mathrm{X}_{3}{ }^{2}=29.93, \mathrm{P}<0.000\right)$ (Figure 2b).

HSP-70 secretion was confirmed in hepatocytes in the liver (Figures $4 \mathrm{a}-\mathrm{b}-\mathrm{c}$ ), in the cytoplasm of the epithelial
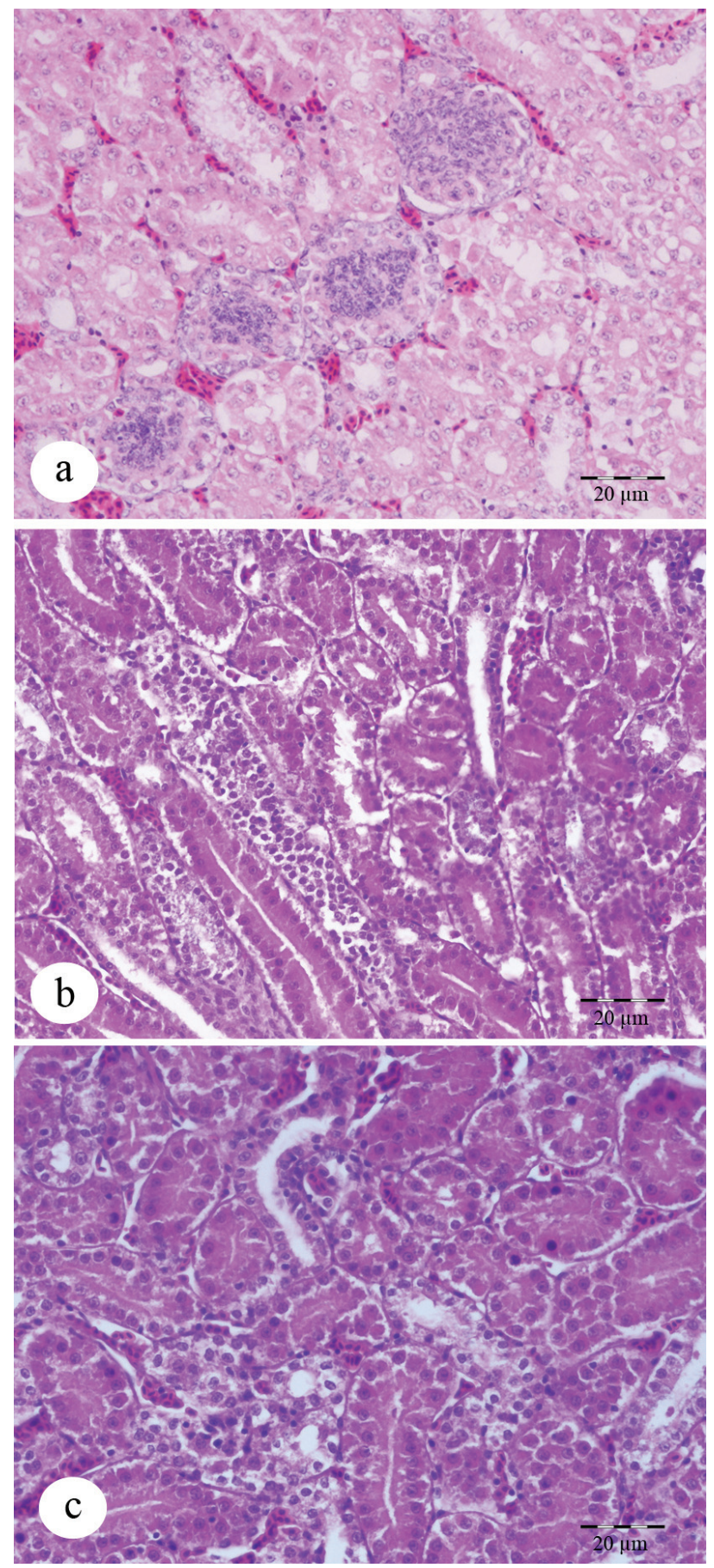

Figures 3a-b-c: Tubulo epithelial degeneration and hyperemic kidney. a. Intensive (Group heat stress), HE., Bar: $20 \mu \mathrm{m}$. b. Moderate (Ascorbic acid), HE., Bar: $20 \mu$ m. c. Weak ( $\alpha$-lipoic acid) HE., Bar: $20 \mu \mathrm{m}$.

Şekil 3a-b-c: Böbrekte tubul epitel hücrelerinde dejeneratif değişiklikler ve hiperemi. a. Yoğun (sıcaklık stresi uygulanan grup), Bar: $20 \mu \mathrm{m}$. b. Orta (Askorbik asit), Bar: $20 \mu \mathrm{m}$ c. Hafif ( $\alpha$-lipoik asit ) Bar: $20 \mu \mathrm{m}$. cells of bile ducts and in endothelial cells of blood vessels, as well as in mesoepithelial cells of the kidney glomerulus and in the cytoplasm of epithelial cells lining the renal tubules (Figures 5a-b-c). The presence of apoptotic cells in the nuclei of the cells mentioned above was inversely proportional to the presence of the protein
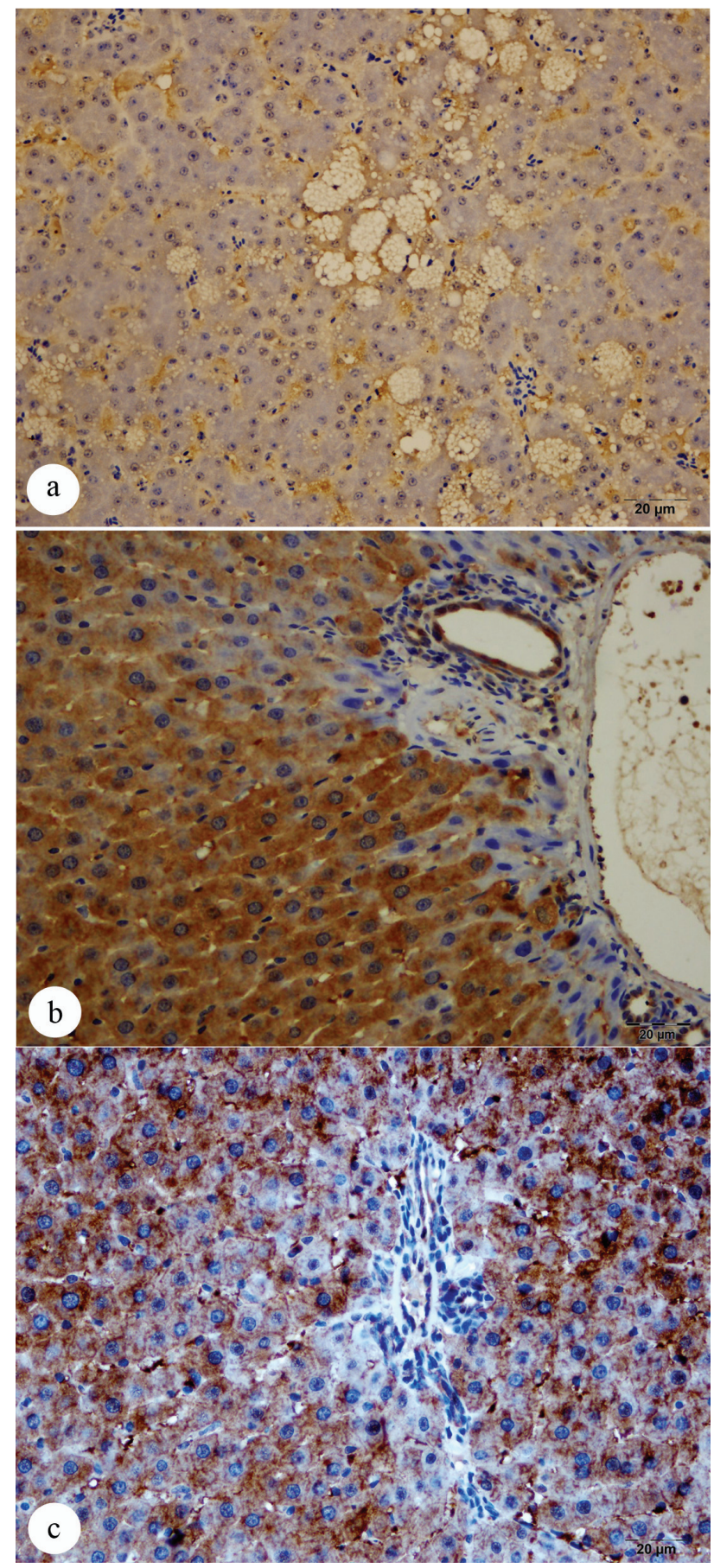

Figures 4: Immunohistochemstry stain; HSP-70 secretion in hepatocytes of liver; a. Weak HSP-70 secretion (Group heat stress), Bar: $20 \mu \mathrm{m}$. b. Intensive HSP-70 secretion ( $\alpha$-lipoic acid ), Bar: $20 \mu \mathrm{m}$ c. Moderate HSP-70 secretion (Ascorbic acid), Bar: $20 \mu \mathrm{m}$

Şekil 4: Immunohistokimyasal boyama; karaciğer hepatosit hücrelerinde HSP-70 sekresyonu; a. Hafif HSP-70 sekresyonu (sıcaklık stresi uygulanan grup), Bar: $20 \mu \mathrm{m}$. b. Yoğun HSP-70 sekresyonu ( $\alpha$-lipoik asit) Bar: $20 \mu \mathrm{m}$. c. Orta şiddette HSP-70 sekresyonu (Askorbik asit), Bar: $20 \mu \mathrm{m}$ 
HSP-70 (Figures 6a-b-c, Figures 7a-b-c). There was apoptotic cells as well as release of HSP-70 in all animals of control group (Figures 2a-b).

Although HSP-70 secretion was determined in the liver in all groups, the marked secretion levels were observed in the HS+AA and HS+ALA groups
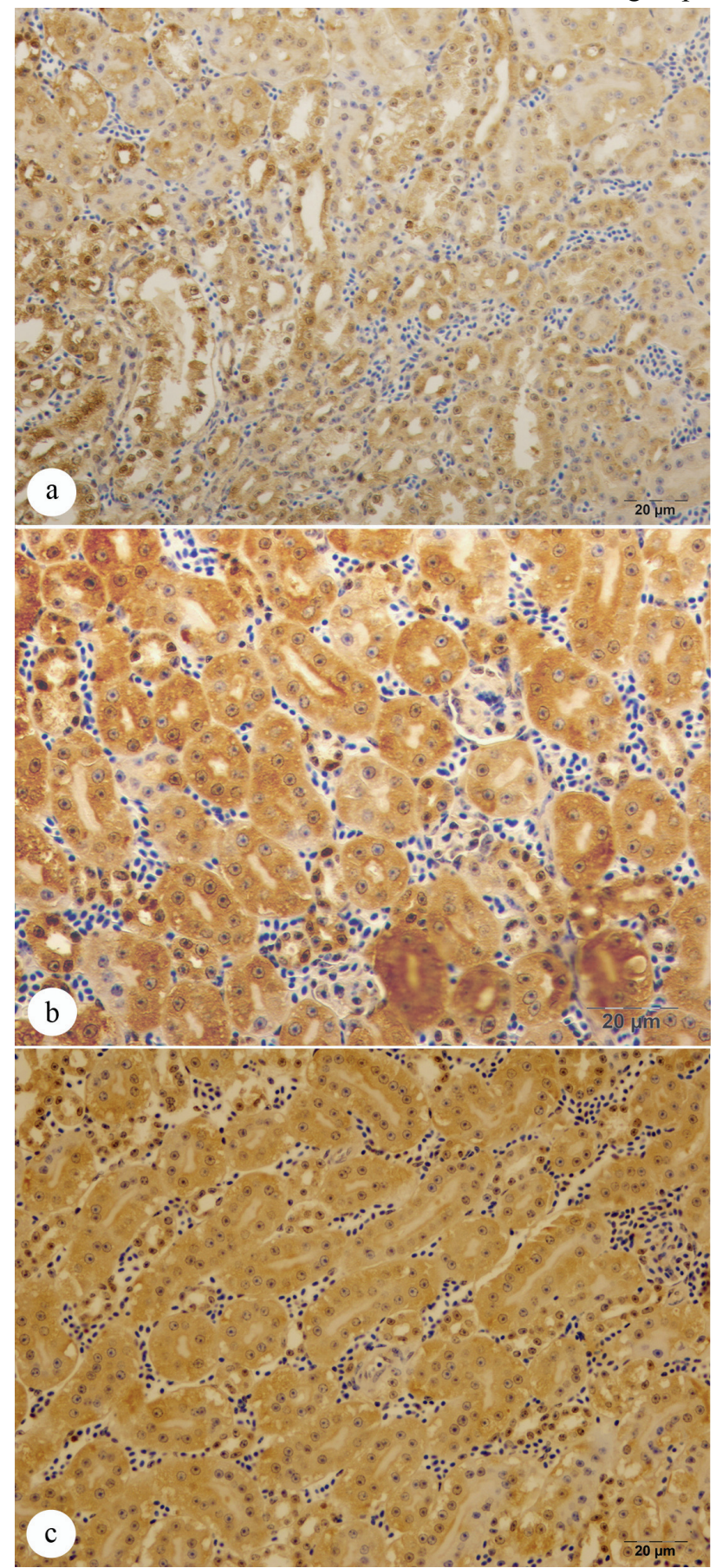

Figures 5: Immunohistochemstry stain; HSP-70 secretion in tubulo epithelial cells of kidney; a. Weak HSP-70 secretion (Group heat stress), Bar: $20 \mu \mathrm{m} . \mathbf{b}$. Intensive HSP-70 secretion ( $\alpha$-lipoic acid), x Bar: $20 \mu \mathrm{m}$. c. Moderate HSP-70 secretion (Ascorbic acid), Bar: $20 \mu \mathrm{m}$.

Şekil 5: Immunohistokimyasal boyama; böbrek tubul epitel hücrelerinde HSP-70 sekresyonu; a. Hafif HSP-70 sekresyonu (sicaklık stresi uygulanan grup), Bar: $20 \mu \mathrm{m}$. b. Yoğun HSP-70 sekresyonu ( $\alpha$-lipoik asit) Bar: $20 \mu \mathrm{m}$. c. Orta şiddette HSP-70 sekresyonu (Askorbik asit), Bar: $20 \mu \mathrm{m}$.
$\left(\mathrm{X}_{3}{ }^{2}=17.96, \mathrm{P}<0.000\right)$ (Figure 2a). However, these two groups did not differ from each other. Contradictory to the results obtained for HSP-70 secretion, the marked number of apoptotic cells in the liver was detected in the HS group, and the lowest number in the HS+ ALA group $\left(\mathrm{X}_{3}^{2}=23.76, \mathrm{P}<0.000\right)$ (Figure $2 \mathrm{~b}$ ).

While HSP-70 secretion in the kidneys was determined in all groups, the marked secretion levels
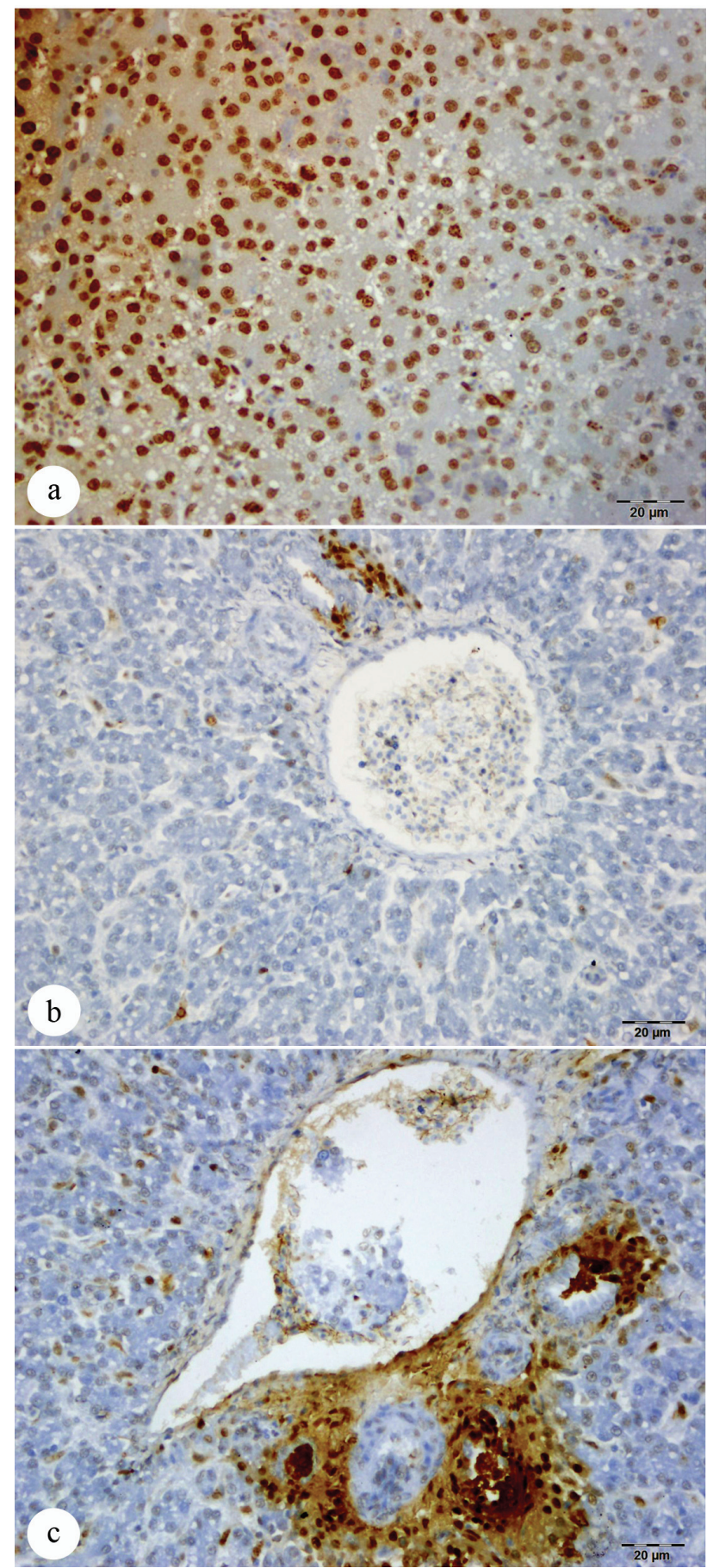

Figures 6: Tunel stain; apoptotic hepatocytes cells in liver; a. Intensive (Group heat stress), Bar: $20 \mu \mathrm{m}$. b. Weak ( $\alpha$-lipoic acid), x Bar: $20 \mu \mathrm{m}$. c. Moderate (Ascorbic acid), Bar: $20 \mu \mathrm{m}$.

Șekil 6: Tunel boyama; karaciğer hepatositlerinde apoptosis; $\mathbf{a}$. Yoğun (sıcaklık stresi uygulanan grup), Bar: $20 \mu \mathrm{m}$. b. Hafif $(\alpha$-lipoik asit ) Bar: $20 \mu \mathrm{m}$. c. Orta (Askorbik asit), Bar: $20 \mu \mathrm{m}$. 
were measured in the HS+AA and HS+ ALA groups $\left(\mathrm{X}_{3}{ }^{2}=20.20, \mathrm{P}<0.000\right)$ (Figure $\left.2 \mathrm{a}\right)$. The marked number of apoptotic cells was determined in the HS group, followed by the HS+AA and HS+ ALA groups, respectively $\left(\mathrm{X}_{3}{ }^{2}=12.20, \mathrm{P}<0.007\right)$ (Figure $2 \mathrm{~b}$ ).

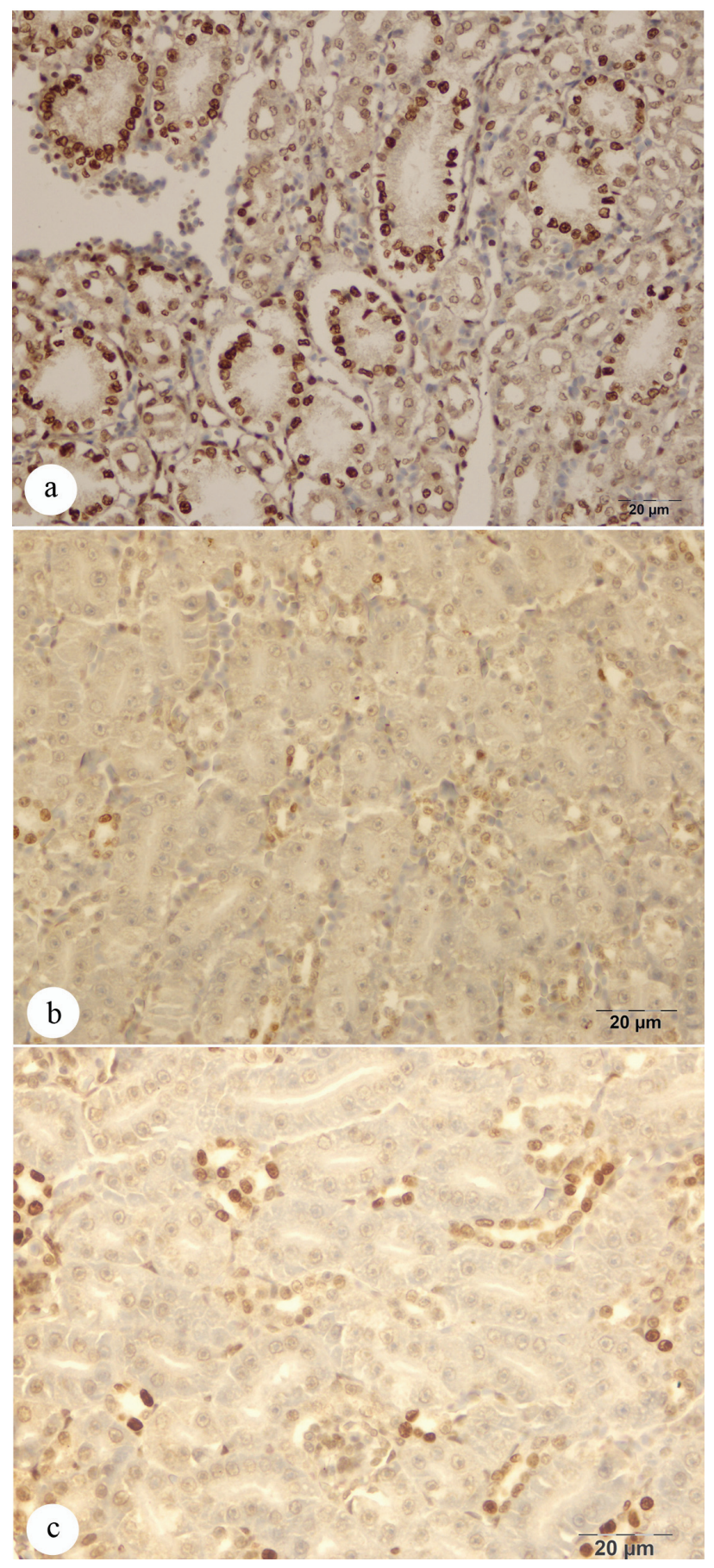

Figure 7: Tunel stain; apoptotic tubulus cells in kidney; a. Intensive (Group heat stress), Bar: $20 \mu \mathrm{m}$. b. Weak ( $\alpha$-lipoic acid), x Bar: $20 \mu \mathrm{m}$. c. Moderate (Ascorbic acid), Bar: $20 \mu \mathrm{m}$.

Şekil 7: Tunel boyama; böbrek tubul epitel hücrelerinde apoptosis; a. Yoğun (sıcaklık stresi uygulanan grup), Bar: 20 $\mu \mathrm{m}$. b. Hafif ( $\alpha$-lipoik asit) Bar: $20 \mu \mathrm{m}$. c. Orta (Askorbik asit), Bar: $20 \mu \mathrm{m}$.

\section{Discussion}

Heat stress is one of the most important environmental stressors. For poultry, the environmental thermoneutral (comfort) (TN) zone covers a temperature range between 18 and $24^{\circ} \mathrm{C}$. When environmental temperature increases above the $\mathrm{TN}$ zone and exceeds the upper critical temperature, the animals are considered to be heat stressed (4).

Heat-stress causes oxidative stress and decreases plasma antioxidant vitamin concentrations $(8,13)$. When the concentration of antioxidant vitamins decreases, lipid peroxidation increases in the plasma and tissues, leading to damage to the integrity of cell membranes (13). Several investigations have demonstrated that heat shock damage occurs in a variety of tissues in poultry $(2,13$, 21). Histopathological examination performed in the present study demonstrated the presence of dense haemorrhagic areas and degenerative alterations in hepatic and renal tissue in broilers subjected to heat stress $\left(34{ }^{0} \mathrm{C}\right)$.

Antioxidants have been shown to inactivate reactive oxygen species (ROS) and thus protect cells from oxidative damage (11). Lower plasma levels of antioxidant substances such as vitamin $\mathrm{C}, \mathrm{E}$ and lipoic acid cause increased oxygen free radicals in stressed poultry. Dietary manipulations are therefore among the methods used to alleviate these negative adverse effects of environmental stress. Several studies have shown that antioxidant nutrient supplementation, especially with $\alpha$ lipoic acid, vitamin $\mathrm{C}$ and $\mathrm{E}$, is effective in preventing the deleterious effects of HS and that these types of nutrients could be included in diets to alleviate the negative effects of heat stress $(14,16)$.

The results demonstrated that the tissue damage observed in liver and kidneys such as degenerative and hiperemic alterations caused by heat stress could be minimized with the administration of $\alpha$-lipoic acid and ascorbic acid $\left(\mathrm{X}_{3}^{2}=28.55, \mathrm{P}<0.000\right)$ (Figure $2 \mathrm{a}$ ).

The HSP-70 family is the most conserved and the most important constituent of the HSP proteins. These proteins are expressed at high levels when cells are exposed to high or low temperatures (14, 24, 31). Previous studies have shown that heat stress is associated with HSP-70 induction, and an increase in the expression of HSP-70 occurred when animals were kept at high ambient temperatures (2). A strong relationship is now recognized between lipid oxidation and HSP-70 synthesis in stressed cells $(15,16)$, and this can be seen in heat stressed poultry species $14,15,21,24)$ Increased HSP-70 secretion having been determined in the liver and kidneys of heat-stressed animals in the present study was in agreement with results obtained in previously conducted studies. 
Previous studies have also demonstrated that levels of $\operatorname{ALA}(6,10)$ and $\operatorname{AA}(14,16)$ are correlated with the secretion of HSP with apoptosis $(9,17)$.

In another study, Sahin et al. (24) reported that serum HSP-70 levels increased in poultry exposed to heat stress, but also indicated that the HSP-70 levels of the groups administered with antioxidants (combination of vitamin $\mathrm{C}$ and $\mathrm{E}$ ) did not differ from the levels measured in the stress group.

An interesting finding obtained in the present study was $\alpha$-lipoic and ascorbic acid-induced increase in HSP70 secretion in liver and kidney tissue as demonstrated by immunohistochemical staining. Based on these results, it was concluded that the antioxidants incorporated into the ration fed to the animals protected cells against the adverse effects of heat stress by increasing HSP secretion in cells.

HSPs make regulatory impact at critical control points of apoptosis by interacting with different apoptotic proteins. Among HSP's, HSP -70 plays an important role in apoptosis. It is determined that HSP 70 prevents caspase-3 activation with inhibition of cytochrome c release and thus inhibites apoptosis (12). It is selected the way to treat by increasing level of HSP protein in treatment of human diseases in medicine today, especially for cancer treatment. Therefore, it is considered to be linked to relationship between HSP protein and apoptosis $(23,25)$.

It is recorded that apoptosis occurs in pathological cases such as infectious bursal disease of poultry (20) and being exposed to radiation (7) as well as a physiologically self-destruction of cell.

It is remarkable that apoptotic cell number in the liver and the kidney tissues of broilers exposed to heat stress is more than those in control group. One another striking finding is that apoptotic cell number in group exposed to heat stress as well as added $\alpha$-lipoic and ascorbic acid to diet is less than those in control and HS group and release of HSP-70 in the group whose diet is supplemented with $\alpha$-lipoic and ascorbic acid is increased.

In conclusion, while heat stress caused damage to liver and kidney tissue in broilers, the addition of alphalipoic and ascorbic acid to the ration increased HSP-70 secretion and reduced apoptosis. Furthermore, it was determined that $\alpha$-lipoic acid was more effective than ascorbic acid in alleviating the adverse effects of heat stress on liver and kidney tissue.

\section{Acknowledgement}

The authors would like to thank the Ataturk University Scientific Research Foundation in Turkey for the financial support (Project No. BAP-2007/184).

\section{References}

1. Alexandrov VY (1994): Function: aspects of cell response to heat shock. Int Rev Cytol, 148,171-227.

2. Bao ED, Gong YY, Hartung J, Hartung J, Fu XB, Wang XJ, Zhang HT, Wang ZL (2004): Relation between pathologic damages and HSP70 changes in acute heat stressed broilers. Scientia Agricultura Sinica, 37, 301305.

3. Cohen JJ, Duke RC, Fadok VA, Sellins KS (1992): Apoptosis and programmed cell death in immunity. Annu Rev Immunol, 10, 267-293.

4. Ensminger ME, Oldfield JE, Heinemann WW (1990): Feeding.108-110. In W.W. Heinemann (Ed). Feeds and Nutrition California: Ensminger Publishing.

5. Gonzalez-Perez O, Gonzalez-Castaneda R (2006): Therapeutic perspectives on the combination of a-lipoic acid and vitamin $E$. Nutr Res, 26, 1- 5 .

6. Gupte AA, Bomhoff GL, Morris JK, Gorres BK, Geiger PC (2009): Lipoic acid increases heat shock protein expression and inhibits stress kinase activation to improve insulin signaling in skeletal muscle from high-fatfed rats. J Appl Physiol, 106,1425-1434.

7. Guler G, Ozgur E, Keleş H, Tomtuk A, Atalay Vural S, Seyhan N (2011): Apoptosis resulted from radiofrequency radiation exposure of pregnant rabbits and their infants. Bull Vet Inst Pulawy, 55, 127-134.

8. Kafri I, Cherry JA (1984): Supplemental ascorbic acid and heat stress in broiler chicks. Poultry Sci, 63, 125-126.

9. Kim JE, Kang JS, Jung DJ, Hahm E, Lee SK, Bae SY, Hwang YI, Shin DH, Lee WJ (2007): Vitamin C induces apoptosis in human colon cancer cells through endoplasmic reticulum stress and mitochondrial pathway. J Immunol, 178, 49-25.

10. Kinnunen S, Hyyppä S, Oksala N, Laaksonen DE, Hannila ML, Sen CK, Atalay M (2009): $\alpha$-Lipoic acid supplementation enhances heat shock protein production and decreases post exercise lactic acid concentrations in exercised standard bred trotters. Res Vet Sci, 87, 462467.

11. Koc M, Imik H, Odabasoglu F (2008): Gastroprotective and anti-oxidative properties of ascorbic acid on indomethacin-induced gastric injuries in rats. Biol Trace Elem Res, 126, 222-236.

12. Lanneau D, Brunet M, Frisan E, Solary E, Fontenay M, Garrido C (2008): Heat shock proteins: essential proteins for apoptosis regulation. J Cell Mol Med, 12, 743-61.

13. Lin H, Decuypere E, Buyse J (2006): Acute heat stress induce oxidative stress in broiler chickens. Comp Biochem Physt A, 144, 11-17.

14. Mahmoud KZ, Edens FW, Eisen EJ, Havenstein GB (2003): Effect of ascorbic acid and acute heat exposure on heat shock protein 70 expression by young White Leghorn chickens. Comp Biochem Phys C, 136, 329-335.

15. Mahmoud KZ, Edens FW, Eisen EJ, Havenstein GB (2004): Ascorbic acid decreases heat shock protein 70 and plasma corticosterone response in broilers (Gallus gallus domesticus) subjected to cyclic heat stress. Comp Biochem Physiol B Biochem Mol Biol. 137, 35-42.

16. Mahmoud KZ, Edens FW (2005): Influence of organic selenium on HSP70 response of heat-stressed and enteropathogenic Escherichia coli-challenged broiler 
chickens (Gallus gallus). Comp Biochem Physiol C Toxicol Pharmacol, 141, 69 -75.

17. Moungjaroen J, Nimmannit U, Callery PS, Wang L, Azad N, Lipipun V, Chanvorachote P, Rojanasakul Y (2006): Reactive Oxygen Species Mediate Caspase Activation and Apoptosis Induced by Lipoic Acid in Human Lung Epithelial Cancer Cells through Bcl-2 Downregulation. J Pharmacol Exp Ther, 319, 1062-1069.

18. Multhoff G (2006): Heat shock proteins in immunity. Handb Exp Pharmacol, 172, 279-304.

19. National Research Council (1994): Nutrient Requirements of Poultry. Edited by the National Academy Press, Washington, DC.

20. Ojeda F; Skardova I; Guarda MI; Ulloa J; Folch H (1997). Proliferation and apoptosis in infection with infectious bursal disease virus: a flow cytometric study. Avian Dis, 41:312-316

21. Pei-Ming S, Yu-Tian L, Qing-Hua W, Zhi-Liang W, En-Dong B (2007): HSP70 and HSP70 mRNA localization in heat-stressed tissues of broilers. Chinese J Agr Biotechol, 4, 181-186.

22. Pirlich M, Kiok K, Sandig G, Lochs H, Grune T (2002): Alpha-lipoic acid prevents ethanol-induced protein oxidation in mouse hippocampal HT22 cell. Neurosci Lett, 328, 93-96.

23. Sharma HS, Muresanu D, Sharma A, ZimmermannMeinzingen S (2010): Cerebrolysin treatment attenuates heat shock protein overexpression in the brain following heat stress: an experimental a study using immunohistochemistry at light and electron microscopy in the rat. Ann NY Acad Sci, 1199, 138-48.
24. Sahin N, Tuzcu M, Orhan C, Onderci M, Eroksuz Y, Sahin K (2009): The effects of vitamin $C$ and $E$ supplementation on heat shock protein 70 response of ovary and brain in heat-stressed quail. Brit Poultry Sci, 50, 259-265.

25. See AP, Pradilla G, Yang I, Han S, Parsa, AT, Lim M (2011): Heat shock protein-peptide coplex in the treatment of glioblastoma. Expert Rev Vaccines, 10, 721-731.

26. Seyrek K, Yenisey C, Serter M, Kiral FK, Ulutas PA, Bardakcioglu HE (2004): Effects of Dietary Vitamin C Supplementation on Some Serum Biochemical Parameters of Laying Japanese Quails Exposed To Heat Stress $\left(34.8^{\circ} \mathrm{C}\right)$. Rev Méd Vét, 155, 339-342.

27. Sherman M, Multhoff G (2007): Heat shock proteins in cancer. Ann NY Acad Sci, 1113, 192-201.

28. Siegel HS (1995): Stress, strains and resistance. Brit Poultry Sci, 36, 3-22.

29. SPSS (1996): Statistical Packages for the Social Sciences for Windows release 10.01. SPSS Inc., Chicago.

30. Van Eden W, van Der Zee R, Prakken B (2005): Heat shock proteins induce $T$ cell regulation of chronic inflammation. Nat Rev Immunol, 5, 318-330

31. Wang S, Edens FW (1998): Heat conditioning induces heat shock proteins in broiler chickens and turkey poults. Poultry Sci, 77, $1636-1645$.

Geliş tarihi: 15.02.2012 / Kabul tarihi: 03.05.2012

Address for correspondence:

Kübra Asena Terim Kapakin,

Atatürk University, Faculty of Veterinary Medicine,

Department of Pathology, Erzurum Turkey.

email: kbraterim@gmail.com 